\title{
Florestan Fernandes: o sociólogo militante
}

\author{
VLADIMIR SACCHETTA
}

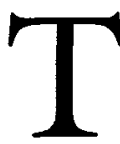

IVE O PRIVILÉGIO DE SER HERDEIRO de uma amizade nascida em 1943, quando meu pai, o jornalista Hermínio Sacchetta, travou conhecimento com um jovem brilhante, aluno da Faculdade de Filosofia, que passou a freqüientar a redação da Folha da Manbã. Com a convivência, além de tornar-se colaborador regular do jornal, Florestan Fernandes foi cooptado por Sacchetta para a militância clandestina no Partido Socialista Revolucionário. Naquela pequena organização trotskista, verdadeira microuniversidade, como lembrava Florestan, abriram-se outros horizontes, responsabilidades e esperanças. Se a ditadura Vargas era seu alvo imediato, a revolução proletária começava a se desenhar como um objetivo essencial e permanente.

Com o passar do tempo, encargos intelectuais, discentes e depois docentes, foram exigindo uma dedicação cada vez maior. Diminuía sua disponibilidade para a ação política, o que criava problemas de consciência no militante devotado e leal. Nesse momento, segundo recordava com muito carinho, foi aconselhado por Sacchetta a optar pelo trabalho na universidade, em tempo integral, onde poderia ser mais útil ao movimento socialista.

Florestan Fernandes refez nos anos 80 o caminho inverso e retornou à militância orgânica, dessa vez no Partido dos Trabalhadores. O Florestan que emergiu aí - e pude testemunhar muito de perto esse marco em seu percurso, acompanhando-o até o final - não era mais aquele jovem dividido diante de duas opções, o PSR ou a Universidade. Tornara-se um homem-sintese, ainda mais radical que, aliando teoria à prática, personificava a ciência como instrumento transformador.

Antonio Candido, muito mais que um amigo de Florestan, distingue três momentos predominantes em sua trajetória: o primeiro, que se situa nos anos 40 - o momento do conbecimento - é o da construção do saber, em que Florestan constrói o seu e a possibilidade de saber dos outros; o segundo, nos anos 50 - o momento da pesquisa aplicada - é o da paixão pela aplicação do saber ao mundo c à sua compreensão; e o terceiro, a partir dos anos 60 - o momento do combatc, o do saber transformado em arma. 




Florestan discursa durante reunião do Partido dos Trabalbadores 
É, portanto, a essas três etapas que ouso acrescentar uma quarta: o da radicalização plena, em que o cientista social, educador e pensador, assume a identidade de tribuno e publicista.

Desde os anos 40, Florestan sempre esteve ligado aos movimentos sociais e reivindicatórios, legais ou ilegais, às organizações políticas de esquerda, clandestinas ou não. Cerrou fileiras ao lado de portugueses e espanhóis antifascistas, fez agitação e propaganda em campanhas memoráveis, como a da Escola Pública, trabalhou com o movimento negro.

Pagou um alto preço por isso. Foi preso após o golpe militar em 64, acabou afastado da Universidade cinco anos depois. Partiu para o exílio e, lá fora, continuou a fustigar a ditadura em meetings de protesto ou através de conferências. Retornou ao país e recusou-se a solicitar sua reintegração à USP, de onde não pedira para sair. Voltou a este campus pela porta do Diretório Central dos Estudantes com um curso sobre Cuba e sua revolução.

Percorrendo-se sua obra é possível perceber no livro Nova República?, editado em 1986, o último trabalho de cunho ensaístico. A partir dali, topamos com uma série de coletâneas de artigos de imprensa - só na Folba de S. Paulo foram mais de trezentas colunas na página 2, entre 1989 e 1995 - que revelam um publicista vigoroso, agudo, implacável e coerente. Cumpriu uma pauta de questões candentes, tratando dos assuntos mais variados. Aperfeiçoou seu estilo e, com a humildade dos grandes homens, o velho professor despiu-se dos vezos da academia para tentar falar uma linguagem mais próxima do povo. Dos de baixo, como dizia.

Filiado ao Partido dos Trabalhadores, Florestan tornou-se deputado federal constituinte em 1986. Seria reeleito em 1990. Nas campanhas, paupérrimas em recursos financeiros, reuniam-se, sob sua inspiração aglutinadora, as mais diversas tendências do arco ideológico de esquerda. Irmanadas em torno de um mesmo sonho: o da construção de uma sociedade nova, com igualdade e, principalmente, felicidade, como frisava Florestan. Contra as idéias da força, a força das idéias, foi o mote da campanha em 86. Sem medo de ser socialista, a palavra de ordem em 1990.

Assumiu a atividade parlamentar numa perspectiva da oposição de esquerda e procurou defender convicções socialistas durante todo o período em que desempenhou os dois mandatos que the foram conferidos. Como sociólogo militante, nunca perdeu de vista a busca de transformações profundas para o país. $\mathrm{Na}$ Comissão de Educação logrou fazer o que foi possível em favor do projeto pelo qual sempre lutou: expandir, modernizar e, em especial, fortalecer a escola pública. Participou ativamente da elaboração da Lei de Diretrizes e Bases, à qual procurou dar o máximo de si. 
Referência para todo o campo da esquerda petista, nunca se ligou a qualquer tendência interna do partido, dialogando com todas elas, principalmente as comprometidas com o socialismo revolucionário. Colaborava, ao mesmo tempo e de forma generosa, com outros partidos e organizações de esquerda, do país e de fora dele.

Militante fiel e disciplinado, aceitava algumas tarefas partidárias de forma crítica, sem jamais deixar de manifestar suas posições, em geral à esquerda da direção. Preocupava-se com os rumos do PT - ou a falta deles - em especial com a ausência de um conteúdo programático de caráter marcadamente socialista. Apontava os perigos da política profissional, do excesso de institucionalização, da burocratização. Conquistar o poder ou simplesmente ocupá-lo? Ser um partido da ordem ou colocar-se contra ela? Estas eram as grandes indagações de Florestan Fernandes com relação ao Partido dos Trabalhadores.

A natureza selvagem do filho de uma imigrante portuguesa explica sua postura e sua personalidade forte, ao mesmo tempo independente e rebelde. Cresceu entre os excluídos - sua maior escola de aprendizado sociológico, como dizia - e nunca perdeu a perspectiva de classe. Nem a crença no socialismo.

Bastante debilitado, driblou a doença até onde pôde. Transformava dor em indignação. Para sobreviver, lutou com a mesma garra daquele menino vindo da ralé, e a conviç̧ão de alguém que ainda tinha muitas tarefas a cumprir. Morreu seis dias após ter enfrentado, com a coragem que cra sua marca, um discutível transplante de figado, talvez a cirurgia mais violenta c agressiva a que um ser humano possa ser submetido.

Em nome de sua família, de scus amigos e de seus companheiros, aproveito a oportunidade desta homenagem para, na presença do magnífico reitor da Universidade de São Pauló, solicitar ao diretor da Faculdade de Medicina que leve à Congregação o debate sobre as questòes médicas, éticas e morais que a operação envolveu. Que o caso possa trazer subsídios à pesquisa no país - em que Florestan acreditava e tanto prestigiou - aprimorando técnicas e procedimentos, democratizando a própria instituiçào e as relações médico-paciente. $\mathrm{E}$ que sua morte não tenha sido em vão. Afinal, Florestan Fernandes era, fundamentalmente, um educador.

Vladimir Sacchetta é jornalista e produtor cultural. Companheiro e amigo de Florestan Fernandes, integrou seu gabinete durante o segundo mandato na qualidade de assessor parlamentar

Palestra feita pelo autor, em nome da família do homenageado, no Ato Presença di Florestan Fernandes, organizado pelo Instituto de Estudos Avançados na Sala do Conselho Universitário da USP em 5 de outubro de 1995. 